\title{
МЕТОДИ КОРЕКЦІЇ ПОСТАВИ У ПАЦІЄНТІВ 3 ІДІОПАТИЧНИМ СКОЛІОЗОМ
}

\author{
Р. А. Бесага, Т. Г. Бакалюк \\ Тернопільський національний медичний університет \\ імені І. Я. Горбачевського МОЗ Украӥни
}

У статті проведено аналіз реабілітаційних підходів, які застосовують для реабілітації пацієнтів 3 ідіопатичним сколіозом. Наведені у статті дослідження мають достатню доказову базу і можуть бути методами вибору при реабілітації пацієнтів з ідіопатичним сколіозом.

\section{METHODS OF THE POSTURE CORRECTION IN PATIENTS WITH IDIOPATHIC SCOLIOSIS}

\author{
R. A. Besaga, T. G. Bakalyuk
}

\section{Horbachevsky Ternopil National Medical University}

The article analyzes the rehabilitation approaches used for the rehabilitation of patients with idiopathic scoliosis. The studies presented in the article have a sufficient evidence base and can be the methods of choice in the rehabilitation of patients with idiopathic scoliosis.

Вступ. Порушення постави $\epsilon$ однією із проблем сьогодення, що відбувається через функціональні зміни опорно-рухового апарату. Основними причинами $є$ малорухливий спосіб життя та тривале сидяче положення. Ідіопатичний сколіоз (IC) у підлітків - це ортопедичне захворювання, поширеність якого становить 2-3 \% у дітей віком 10-16 років [9]. Найважливішими завданнями для відновлення рухового стереотипу при цій групі захворювань $\epsilon$ виправлення дефекту постави, підвищення тонусу м'язів, покращення стану серцево-судинної та дихальної систем, загальне зміцнення організму.

Основна частина. До найпоширеніших методів корекції рухового стереотипу в пацієнтів із порушенням постави належать: лікувальна гімнастика, масаж та мануальна терапія, вправи на тренажерах, носіння ортопедичних корсетів та поясів.

Більшість експертів погоджується, що лише одні вправи не вплинуть на зменшення прогресування структурного сколіозу. Проте $\epsilon$ думка, що селективна програма вправ у поєднанні з загальнозміцнювальним лікуванням - корисна. Крім того, у низці досліджень показано, що фізичні вправи можуть мати позитивний вплив на функцію дихання, силу

(ㄱ Р. А. Бесага, Т. Г. Бакалюк, 2021 і постуральну рівновагу, а також вони корисні для зменшення конкретних порушень та інвалідності пацієнтів з ідіопатичним сколіозом [4, 11].

Ряд досліджень стверджує, що вправи потрібно виконувати з урахуванням активної самокорекції і вони мають бути спрямовані на стабілізацію хребта, зміцнення тонічних м'язів, поліпшення балансу і координації, відновлення і підтримання фізіологічних сагітальних вигинів. Фізичні терапевти уникають збільшення діапазону рухів хребта, а замість цього зосереджуються в основному на стабільності хребта $[6,11]$.

Програма вправ за Schroth [13] складається з корекції сколіотичної постави і патерну дихання за допомогою пропріоцептивної та екстероцептивної стимуляції і дзеркального контролю. За допомогою вправ Schroth намагаються досягти цієї корекції, використовуючи тільки активну силу м'язів тулуба. Таким чином, пацієнти вчаться підніматися якомога далі з положення виключно пасивної підтримки зв'язок спини, що, як вважається, сприяє прогресуванню викривлення, а потім підтримує виправлену поставу в повсякденній діяльності.

Кілька когортних досліджень методу Schroth показали позитивні результати щодо сили м'язів спи- 
ни [13], функції дихання [13], сповільнення прогресування сколіотичної кривої [16], поліпшення кутів Коба $[13,16]$ і зменшення частоти хірургічних втручань [14]. Шестимісячне рандомізоване клінічне дослідження (РКД), проведене в 2015 р. [16], показало зменшення болю, самооцінки і витривалості м'язів спини у пацієнтів з IC порівняно зі стандартним лікуванням.

Інше РКД [8] показало, що програма добре спланованих індивідуальних вправ Schroth під наглядом фізіотерапевта $\epsilon$ ефективним методом збільшення регресу або зупинки прогресування ідіопатичного сколіозу в підлітків.

Ще одним методом корекції ідіопатичного сколіозу $є$ кінезіологічне тейпування (КТ). Застосування КТ призводить до полегшення болю в спині відразу після приклеювання стрічки. Крім того, КТ позитивно впливає на якість життя і може бути відповідним втручанням у лікування болю в спині пацієнтів з IC [1]. Ідея цієї методики ґрунтується на створенні вільного діапазону рухів, щоб дати можливість м'язовій системі самолікуватися біомеханічно і бути опорою для руху. Застосування КТ піднімає шкіру, таким чином збільшуючи проміжний простір дерми та підшкірної клітини та зменшуючи тиск у цій ділянці. Як наслідок, використання КТ $є$ ефективним для збільшення кровотоку і руху в патологічно зміненій ділянці, що призводить до зменшення запалення. Це також зменшує подразнення хімічних рецепторів. Зменшення болю, у свою чергу, поступається місцем поліпшенню функцій м'язів, зменшенню активації нервово-м'язової системи кровообігу та лімфообігу, а також прискоренню кровотоку та загоєнню тканин. Вважається, що методика також безпосередньо зменшує біль, активуючи механорецептори шляхом накладання стрічки безпосередньо на шкіру [1]. Методологічна якість, включених РКД, була хорошою, середня оцінка 6,6 за 10-бальною шкалою PEDro. Однак дані дослідження [12] свідчать про те, що КТ як єдине лікування або у поєднанні з іншим лікуванням не $є$ більш ефективним, ніж звичайна фізіотерапія та фізичні вправи щодо полегшення болю.

Методи мануальної терапії також застосовують в лікуванні IC. Мануальна терапія призначена для збільшення діапазону рухів суглобів, модуляції розтяжності тканин/м'язів, покращення обмеження рухів м'яких тканин, полегшення болю та сприяння психологічному благополуччю. Ряд РКД оцінював вплив мануальної терапії на лікування IC, особливо в Китаї [7]. РКД, що проведено у 2004 р., показало, що після 4-6 тижнів застосування мануальної терапії відбулось зменшення кута Коба в середньому на 17 градусів. У жодного з пацієнтів кут Коба не збільшився [10].

Також методом успішного лікування IC $€$ застосування системи SpineCor. Динамічний брекет SpineCor для лікування ідіопатичного сколіозу призначений для підтримки правильного положення хребта та нової стратегії руху протягом 20 год на день. Суть цієї методики полягає в підтримці рухливості хребта, одночасно досягаючи положення, в якому виправляються всі складові триплощинної деформації. Ортез SpineCor $\epsilon$ ефективним способом лікування ювенільного ідіопатичного сколіозу і дає позитивний результат лікування в довгостроковій перспективі. Ортез ефективний для більш м'яких кривих (<25 градусів), а також для помірних кривих (26-45 градусів) порівняно з історією захворювання. Ефективність ортопедичного лікування системою SpineCor підтверджується його здатністю відкладати хірургічне лікування. Серед тих, хто пройшов курс лікування цим ортезом, корекція зберігається в довгостроковій перспективі, оскільки 75 \% пацієнтів стабілізували кут Коба $[4,5]$.

3 альтернативних методів для лікування IC використовують голкорефлексотерапію, яку зазвичай використовують для усунення м'язово-скелетного болю та спазму м'язів. Деякі методи стимуляції голковколюванням можуть або тонізувати, або заспокоювати енергію на меридіанах. Вважається, що тонізування ділянок слабких м'язів та заспокоєння ділянок надмірно активних м'язів можуть мати розслаблювальний і врівноважувальний ефекти. На сьогодні опублікована невелика кількість досліджень, і вплив голковколювання при реабілітації пацієнтів зі сколіозом потребує подальшого вивчення [3].

Ще однією методикою, яку застосовують під час лікування IC, є науковий підхід до вправ при сколіозі (Scientific Exercise Approach to Scoliosis - SEAS). Метод SEAS - це метод лікування сколіозу, який зосереджений на відновленні постурального контролю та покращенні стійкості хребта за допомогою вправ, що включають активну 3D-корекцію сколіотичної постави. Активна 3D-самокорекція досягається спочатку шляхом навчання пацієнтів та підвищення обізнаності пацієнта про їх деформацію. Як тільки пацієнт усвідомлює свою деформацію та необхідні 
зміни для її виправлення, пацієнт може свідомо вносити корективи у свою поставу (активна самокорекція), щоб знайти найкраще вирівнювання хребта у тривимірних просторових площинах. Потім метод SEAS фокусується для стабілізації хребта та підтримки постави за допомогою різноманітних вправ відповідно до деформації, щоб допомогти досягти кінцевої підсвідомої самокорекції постави шляхом стимуляції нейросенсорних механізмів її підтримки. Активну тривимірну самокорекцію можна відтворити у тисячі різних вправ із «відволікаючими» ситуаціями, які вимагають від нервово-м'язових зв'язків підвищення стабільності під час виконання рухів, щоденних дій та таких вправ, як сидіння - стояння, підйом і спуск по сходах, балансування на одній нозі, тим самим «зміцнюючи» нервово-м'язові зв'язки, які беруть участь у корекції постави та нейромоторній реабілітації [2].

Одна з принципових відмінностей методу SEAS від інших методів лікування сколіозу полягає в тому, що немає жодної єдиної вправи, яка вважалася 6 кращою за інші. Метою лікування SEAS $\in$ постуральна реабілітація за допомогою все більш складних вправ, які кидають виклик пацієнту досягти та підтримувати активну самокорекцію. Завдяки

\section{СПИСОК ЛІТЕРАТУРИ}

1. The effect of Kinesio taping on back pain in patients with Lenke Type 1 adolescent idiopathic scoliosis: A randomized controlled trial / Y. Atici, C. G. Aydin, A Atici [et al.] // Acta Orthop. Traumatol. Turc. - 2017. - Vol. 51(3). - P. 191-196. doi: 10.1016/j.aott.2017.01.002. Epub 2017 Mar 19.

2. Physiotherapy scoliosis-specific exercises - a comprehensive review of seven major schools / $\mathrm{H}$. Berdishevsky, V. A. Lebel, J. Bettany-Saltikov [et al.] // Scoliosis Spinal Disord. - 2016. - Vol. 4, No. 11. - P. 20.

3. Canavese F. Adolescent idiopathic scoliosis: Indications and efficacy of nonoperative treatment / F. Canavese, A. Kaelin // Indian J. Orthop. - 2011.

4. Coillard C. A new concept for the non-invasive treatment of Adolescent Idiopathic Scoliosis: the Corrective Movement principle integrated in the SpineCor System / C. Coillard, A. Circo, C. H. Rivard // Disabil. Rehabil. Assist. Technol. 2008.

5. Coillard C. SpineCor treatment for Juvenile Idiopathic Scoliosis: SOSORT award 2010 winner / C. Coillard, A. B. Circo, C. H. Rivard // Scoliosis. - 2010.

6. Grivas T. B. The conservative Scoliosis treatment / T. B. Grivas. - Amsterdam: los Press, 2008. послідовності коригувальних рухів, характерних для типу кривої пацієнта, пропонується досягти якомога більш фізіологічного вирівнювання хребта. Активна самокорекція вздовж трьох просторових площин $\epsilon$ найважливішою складовою SEAS [2].

Отже, при наявності у пацієнтів ідіопатичного сколіозу доцільним буде використання вправ за програмою Schroth для збільшення регресу, це відбувається за рахунок використання активної сили м'язів тулуба. Застосування КТ $є$ ефективним для збільшення кровотоку і руху в патологічно зміненій ділянці, що призводить до зменшення запалення. Методи мануальної терапії спрямовані на збільшення діапазону рухів. Ортез SpineCor ефективний для зменшення кривизни, а також для стабілізації кута Коба. Переваги методу SEAS в тому, що вправи виконуються у тривимірних площинах, а також залучають свідомість пацієнта.

Висновки. Наведені у статті дослідження показують, що застосування фізичних вправ за методом Schroth, використання кінезіологічного тейпування, мануальної терапії, ортезів SpineCor та методу SEAS $\epsilon$ ефективними і можуть бути методами вибору при реабілітації пацієнтів з ідіопатичним сколіозом.

7. Manual therapy for idiopathic scoliosis: A protocol for systematic review and meta-analysis / Q. Huang, L. Zhang, Z. Li, L. Kong // Medicine (Baltimore). - 2020.

8. Kuru Tuğba The efficacy of three-dimensional Schroth exercises in adolescent idiopathic scoliosis: a randomised controlled clinical trial / Tuğba Kuru // Clinical rehabilitation. - 2016. - Vol. 30.- P.181-190.

9. Lotan S. Manual therapy treatment for adolescent idiopathic scoliosis / S Lotan, L. Kalichman // J. Bodyw. Mov. Ther. - 2019.

10. Morningstar M. W. Scoliosis treatment using a combination of manipulative and rehabilitative therapy: a retrospective case series / M. W. Morningstar, D. Woggon, G. Lawrence // BMC Musculoskelet Disord. - 2004. Vol. 14 (5). - P. 32.

11. Specific exercises reduce brace prescription in adolescent idiopathic scoliosis: a prospective controlled cohort study with worst-case analysis [electronic version] / S. Negrini, F. Zaina, M. Romano, S. Parzini // J Rehabil Med. 2008. - Vol. 40. - P. 451-455. fckLRLevel of evidence: 1.

12. Nelson N. L. Kinesio taping for chronic low back pain: A systematic review / N. L. Nelson // J. Bodyw. Mov. Ther. -2016. 
13. Otman S. The efficacy of Schroth s 3-dimensional exercise therapy in the treatment of adolescent idiopathic scoliosis in Turkey / S. Otman, N. Kose, Y. Yakut // Saudi Med. J. - 2005. - Vol. 26. - P. 1429-1435.

14. Rigo M. Effect of conservative management on the prevalence of surgery in patients with adolescent idiopathic scoliosis / M. Rigo, C. Reiter, H.-R. Weiss // Pediatr Rehabil.2003. - Vol. 6. - P. 209-214.

15. Schreiber Sanja The effect of Schroth exercises added to the standard of care on the quality of life and muscle endurance in adolescents with idiopathic scoliosis-an assessor and statistician blinded randomized controlled trial:SOSORT 2015 Award Winner / Sanja Schreiber // Scoliosis . - 2015. - Vol. 10. - P. 24.

16. Weiss H.-R. Incidence of curvature progression in idiopathic scoliosis patients treated with scoliosis in-patient rehabilitation (SIR): an age- and sex-matched controlled study / H.-R. Weis., G. Weiss, F. Petermann // Pediatr. Rehabil. - 2003. - Vol. 6. - P. 23-30. 